\title{
All roads lead to advertising: Use of proverbs in slogans
}

Helena Margarida Vaz Duarte, Rosa Lídia Coimbra and Lurdes de Castro Moutinho

Department of Languages and Cultures, University of Aveiro, Portugal

https://doi.org/10.36505/ExLing-2006/01/0055/000055

\begin{abstract}
This paper presents a research on the use of proverbs in written advertising texts from Portuguese press. The analysis focus on the presence of the proverb in the text both changed and unaltered. The different strategies of transformation are presented.
\end{abstract}

\section{Introduction}

Proverbs are wise sayings, short definitions of wisdom (Mieder, 1999). When we hear or read the sentence "All roads lead to Rome" we will easily recognize that we have encountered a proverb. It will, for sure, sound familiar. This characteristic is used in advertisement slogans in order to attract the reader's attention. Being familiar with the sentence, the reader will feel more involved and the product will be presented as something close to the consumer.

The corpus of this research includes forty three written advertisements published in Portuguese press and also in outdoors, all of them including a proverb in the slogan.

In our corpus, these proverbs are sometimes left unaltered. But most of the times some kind of alteration is made to the sentence. In this paper, we show the type of changes performed in these slogans and their importance to the persuading power of the message. Several strategies are used to modify the proverb such as: lexical exchanges, syntactic alterations, elisions.

The use of proverbs and these strategies are also present in other text types, namely literary (Duarte Mendes, 2000; Nunes; Duarte, 2004) and journalistic (Coimbra, 1999).

\section{Altered and unaltered proverbs}

In our corpus, we noticed that in the great majority of the cases there is an alteration of the fixed form of the proverb. As can be observed in Figure 1, the difference is notorious. In fact, there are 13 cases in which there is no transformation on the linguistic form and the meaning of the proverb is also preserved.

ExLing 2006: Proceedings of 1st Tutorial and Research Workshop on Experimental Linguistics, 28-30 August 2006, Athens, Greece 


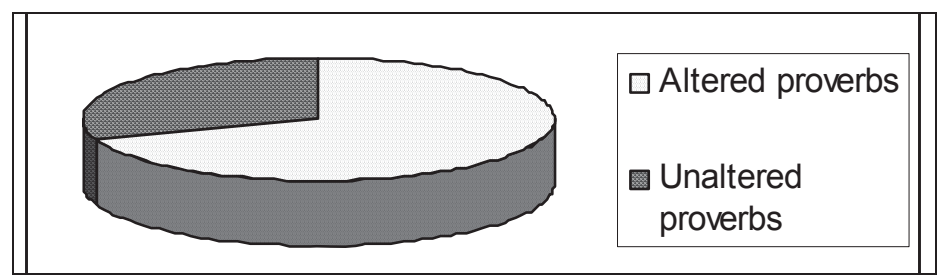

Figure 1. Altered and unaltered proverbs

Concerning the 30 altered forms, we may observe several different processes of transformation. The strategies may be grouped into three categories.

\section{Lexical replacement}

Among the 30 sentences that were altered, 22 were by lexical replacement, which means that this is the most preferred strategy. The replacement is accomplished by substituting one or more words of the original proverb by one or more words concerning the characteristics of the product advertised.

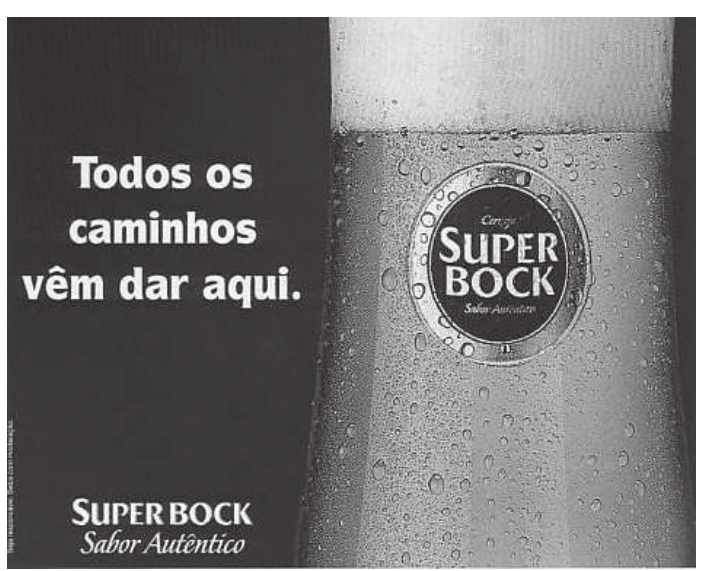

Figure 2. Example of lexical replacement

For example, as can be seen in figure 2, the proverb Todos os caminhos vão dar a Roma (All roads lead to Rome) is changed by substituting the word vão (go) by vêm (come), and the word Roma (Rome) by aqui (here). This place adverb means the advertised product, a beer.

\section{Syntactical changes}

With 7 occurrences, we found cases where the alteration of the fixed form was made on the syntactical level. The main process is the change of the 
sentence form or type. Declarative is changed to interrogative; negative is changed into affirmative and vice-versa.

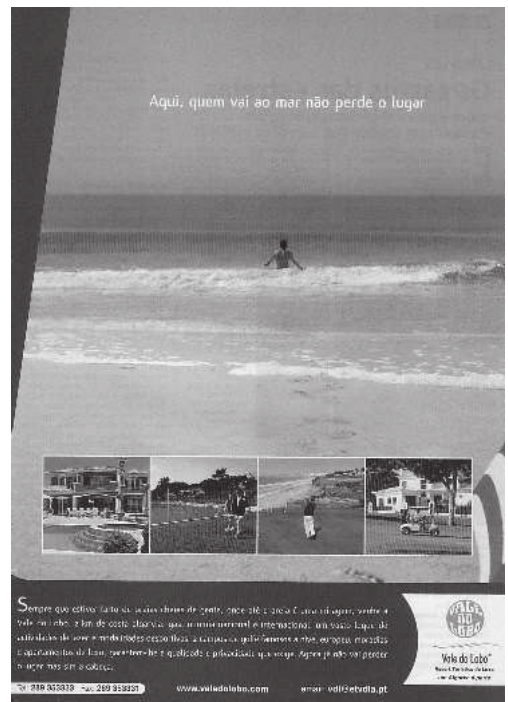

Figure 3. Example of syntactical change

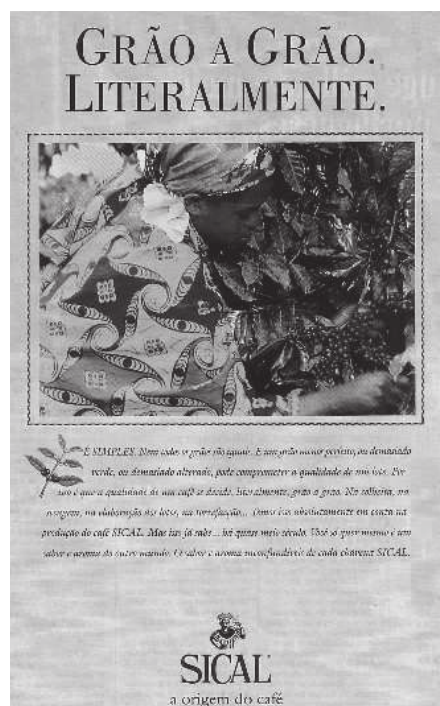

Figure 4. Example of lexical suppression

Figure 3 shows an example of a syntactical change in the proverb Quem vai ao mar perde o lugar (meaning that if you go away someone may take you place). The sentence, which originally was affirmative, is, on the slogan, negative. Thus, there is an emphasis on the quality and privacy of the touristic resort advertised.

\section{Lexical suppression}

Finally, we found an example in which the alteration consists on suppressing the final part of the proverb.

The fixed form of the proverb, Grão a grão enche a galinha o papo (Slowly, slowly catchy monkey) is reduced to Grão a grão. Furthermore, the slogan adds the adverb Literalmente (literally) directing the reader's interpretation to the preoccupation on the careful selection of the coffee grains of the advertised brand.

\section{Conclusion}

We conclude that the majority of the slogans containing proverbs presents an alteration on its form, mainly due to lexical replacements. 
In future, oral advertisements (radio and television) can also be studied in order to see if these or other strategies (prosodic clues, e.g.) are also used.

Another possibility of expanding this study is to verify the reader's skill to identify the original proverb as well as the meaning and intention of the altered form.

\section{References}

Coimbra, R. L. 1999. Estudo Linguístico dos Títulos de Imprensa em Portugal: A Linguagem Metafórica. (thesis), Universidade de Aveiro.

Duarte Mendes, H. M., 2000. Estudo da Recorrência Proverbial - de Levantado do Chão a Todos os Nomes de José Saramago (thesis). Universidade Nova de Lisboa.

Mieder, W. 1999. Popular Views of the Proverb, vol. 5, n. 2. $<$ http//www.deproverbio.com>

Nunes, A. M.; Duarte Mendes, H. M. 2004. Alguns aspectos da refomulação parafrástica e não parafrástica em José Saramago e Mia Couto. In Actas do XIX Encontro Nacional da Associação Portuguesa de Linguística. Lisboa: APL, 623630 . 